\title{
Students Success in Mathematics and Its Relationship with the Attitude toward Numeracy Learning
}

\author{
Darmiyati \\ Education of Elementary School Teachers \\ Universitas Lambung Mangkurat \\ Banjarmasin, Indonesia \\ darmiyati.fkip@gmail.com
}

\begin{abstract}
This research aims to determine students' success in mathematics and its relationship with the attitude toward numeracy learning. This research was held at the SDN Cindai Alus 1 Banjar district Academic year 2015-2016. The research lasts for three months from January until March 2016. The method used in this study was a survey correlation technique. The target population of this research was all students of SDN Cindai Alus 1 Banjar. The population was the fourth grade students who are taking math lesson. The total sample as a whole was 60 students. The instruments to retrieve the data were in the form of questionnaires and documentary. The aspects of students attitudes toward math lessons that were observed in this study includes cognition, affection and conation. The results showed that: (1) the value significance of students' attitudes toward math was greater than a 0.05 which was 0.56 and normally distributed; (2) the variance of the relationship between students' attitudes toward math lesson with students success in mathematics expressed linearly with $F$ count $<F$ table $(2,626<4: 00)$; (3) there is a significant relationship between students' attitudes toward math lesson with students success in learning math in elementary school where $R$ count $>R$ table $(0423>0254)$; and (4) the more positive students attitudes toward math lesson, the higher the students' success in learning math.
\end{abstract}

\section{Keywords-Attitudes, Learning Math, Learning Outcomes}

\section{INTRODUCTION}

Improving the quality of human resources can not be separated from how education can produce skilled manpower in their respective fields, or in other words, graduates of the high quality educational process. Education begins from elementary school to university/college. In this process, basic education is one of the main determinants of the success of national education. This is because basic education is a prominent foundation which is decisive in the formation of students attitudes and intelligence. On this basis, the effort to improve the quality of basic education is a determining factor for the success of efforts to improve the quality of national education. It is arranged in the Government Regulation No. 19 of 2005, 3 stating that "The purpose of primary education is laying the foundation of intelligence, knowledge, personality, character, and skills to live independently and to follow further education. To achieve the objectives referred, Kemendikbud (Ministry of Education and Culture) enacts 2006 curriculum where coverage among other groups of subjects in science and technology including elementary math lesson.
Mathematics is important in everyday life when it is seen by the things related to science, both in the field of exact and in other knowledge fields that require math. On the other hand, a lot of students have difficulties in learning mathematics compared to other subjects. Various efforts have been initiated and developed continuously by the government, private sector, or group of teachers' professional organizations, ranging from the improvement of the curriculum, providing workshop associated with the implementation of curriculum, provision of textbooks, learning and CAR (Classroom Action Research) training strategies, complementary means of infrastructures, and other mathematics props.

In fact, the students ability in the learning mathematics is still weak. In addition, there is still less impact of students mastery in mathematics learning outcomes. Their learning outcomes are still low as has been seen from observations and interviews with the teachers where this research was carried. The daily tests score, the task of training given to students both at school as well as home and mathematics test results obtained the average score of 50.5. It has not reached a score of 65 according to the standardized set KKM (Minimum Graduation Criteria).

The results of mathematics learning is supported by the research conducted by Susanto, showing that the results of school exams (UN and UASBN) average learning score outcomes of primary school students was between 5 and 6 , and even smaller than that. These results indicated that the students ability in math is still low [1]. The results of the evaluation of low quality of education in mathematics, conducted by "The Third International Mathematics and Science Study-Repeat" [2] reported that students' mastery in basic education $\left(2^{\text {nd }}\right.$ grade junior high scool) in mathematics surveyed internationally put Indonesia on $36^{\text {th }}$ ranks out of 49 countries. The score obtained by the average 397 points from the average standard international score of 500 [2].

Based on these data, it can be inferred that the mastery of math concepts of elementary school students learning process is still not implemented optimally, whereas the students' mastery in mathematics would be a means to help a variety of subjects both at the same education level or at a higher level. The efforts and activities that have been implemented in order to improve the learning process, especially in improving the learning results still do not meet the expectations of the government, the public, as well as parents and teachers, who 
teach in schools, not just math skills, and learning results are still lack even the students who behave negatively on their math lessons assuming that math is such a desperate lesson, this view shows the students' attitudes toward math.

A positive attitude in mathematics is very important and needs to be shared by all students so they can feel pleased to accept the lesson attentively and actively involved in the study and the individual task or in groups and finally getting better learning. It is supported by the research results by Lin Shu-Hui which showed students' attitudes toward math plays an important role in the learning process for students with a positive attitude in mathematics correlated with higher student achievement [3].

In connection with the above description, fundamental repairs are needed in terms of both internal and external in the implementation of learning mathematics. One of the internal factors that can be carried out to see increased students success in mathematics is to investigate the relationship between students' attitudes toward arithmetic learning with outcomes of mathematics.

This study aims to determine the students success in mathematics and its relationship with the attitude toward arithmetic learning in the fourth grade students of SDN Cindai Alus 1 Kab. Banjar.

\section{A. The Nature of Learning Outcomes}

Russell [4] gives the sense that "Mathematics is the queen of the sciences" mathematics acts as both queen and servants to another science. Higgens stated math is the science of learning concepts, symbols and the relationship between the two [5].

Similar opinion was expressed by Daen that mathematics is influenced by the development and advancement of technology and the development and progress of science. Math is a mental activity to understand the meaning of relationships and symbols which contain in mathematics systematically, carefully and rightfully, and then applying the resulting concepts to solve problems in different ways, circumstances or real situations. To assess the success or failure of students in learning, it should be measured through achievement test.

Groundlund gives the sense that the learning outcomes are a number of abilities of the students as a result of learning activities [6]. Then Suprijono [7] stated that learning outcomes are patterns of action values, understanding the attitudes of appreciation and skills.

Five basic ability as result of learning are intelectual skills, cognitive strategies, verbal information, motor skills, and attitudes that have become private property and allow it to do something [8]. The lhe learning outcomes can be measured in two dimensions: (1) the level of performance with the indicator to remember, to understand, to use, and to find (2) the type of field of study with the indicator is facts, concepts, procedures, and principles [9].

The amount of time spent on reading theory, writing or answering questions, following by the math lesson, studying materials of mathematics both from teachers and other sources will have a very positive relationship with the results of students' mathematics learning.

Based on the description of the theory that has been stated above, we conclude that mathematics is the study of a collection of ideas that are abstract, with the structures and relationships are arranged according to a logical sequence and utilizing the method of deductive reasoning. It is also a tool that helps to solve problems of other sciences, both fields of exact and nonexact (especially problems relating to the calculation). In addition, based on the opinions and thinking of the experts that have been uncovered above, it can be concluded that the results of learning mathematics is students' mastery of subject matter previously gaining learning experience shown by students through teacher's test scores.

\section{B. The Nature of Students Attitudes toward Numeracy Lesson}

Attitude is one element of personality that must be held to determine the actions and behave to an object is accompanied by positive and negative feelings. Attitude is a system that is settled inside the individual in the form of positive and negative assessment in which there is a tendency to accept or reject [10]. The same opinion is expressed by Sanjaya that attitude is a person's tendency to accept or reject an object based on the value he/she thinks is right [11].

Students' attitudes toward the math subject cannot be separated from his perception, his way of thinking, attention, interest, memory, etc. Mathematics is one of the objects of psychology that can be connected with positive and negative feelings. Thus, the students' attitudes toward mathematics courses can be seen from the way he responded to the subjects of mathematics in the classroom and outside the classroom. Students need to have a positive attitude toward the subject, students' positive attitude will grow and develop interest, motivation to learn and easy to absorb the subject matter provided. Anwar reiterated in more details that a person's attitude toward an object always plays a role as an intermediary between its responses to the relevant object. The respond includes cognitive, affective and conative [12].

Similarly, students' attitude toward math is shown through feelings and assessment of the benefits of lessons given. Students who have a sense of interest in this learning can foster the interest in learning and feel pleasure in doing the teachers assignment. If the students have grown the interest, it will be followed by willingness of the students to receive lessons given. Similarly, the assessment of the benefits associated with a math lesson. When students know and realize that math is useful to support in learning other sciences as well as for a judgment, it will affect the study results.

Feeling, willingness and assessment of arithmetic given benefit is the positive attitude of students toward these subjects. Students who were positive about math would classify math as a fun and interesting lessons to be learned with his own consciousness not merely because of the demands of the curriculum and teacher. On the contrary, students who feel negative on math classify math as a boring, unattractive and consider mathematics a waste of time to learn, and work on a job involuntarily. 
So the meaning of students' attitudes toward arithmetic in this paper are internal factors that influence the students and are a manifestation of feelings, a willingness and assessment of arithmetic presented and developed by teachers including interest, curiosity, enthusiasm, accuuracy, independence, and the benefits and uses of arithmetic accompanied by positive and negative feelings.

\section{METHOD}

The research was conducted in the fourth grade of SDN Cindai Alus 1 Banjar district from January to March 2016. The method used in this study was a survey correlation technique. The target population of this study was all students of the Elementary Schools in Banjar District Region academic year $2015 / 2016$, while the sample was the fourth grade students at SDN Cindai Alus I in a number of 60 students.

The data collection techniques used questionnaires, tests, and documentaries. Questionnaire techniques used to collect students data of the attitudes toward arithmetic (X1), while the data on students learning outcomes in math (Y) used documentary techniques namely by taking the score of the test that has been given by mathematics teacher in the first half of semester.

The collected data were were analyzed using descriptive statistics and inferential statistic. The inferential analysis was used in accordance with the required tests, including tests of normality, linearity, and hypothesis testing research on each variable.

\section{RESULTS AND DISCUSSIONS}

The research instrument used in this study consisted of two types, namely the students learning outcomes and the attitudes toward mathematics and arithmetic. The instruments were not tested because the test has been created by the teachers and have already tested to students. Instruments of students attitudes toward math subjects were tested with 50 point statement, and after tested, 10 points were invalid and only 40 points that were used for research. The results of the test instrument turned out that students attitudes toward arithmetic has a very high reliability. This is shown by the price of $\mathrm{R}=0.95$.

TABLE I CORRELATIONS

\begin{tabular}{|ll|l|l|}
\hline & & Attitudes & Results \\
\hline attitudes & Pearson Correlation & 1 & $423^{* *}$ \\
& Sig. (2-tailed) & &, 001 \\
& N & 60 & 60 \\
\hline results & Pearson Correlation &, $423^{* *}$ & 1 \\
& Sig. (2-tailed) &, 001 & \\
& N & 60 & 60 \\
\hline
\end{tabular}

a. $* *$. Correlation is significant at the 0.01 level (2-tailed)

Based on the calculation results showed that the students' attitudes toward math lessons obtained the maximum score 113 and minimum score of 60 , an average of 91.25 , and a standard deviation of 10.83 .

Normality test data used Kolmogorov-Smirnov test. To determine the normality of the data, it used the Asymp value comparison. Sig.2-tailed at the alpha level of 0.05 (Syarifudin, 2010: 143). The test results are presented in Table II.

TABLE II NORMALity Test DATA By One-SAmple KolmogorovSMIRNOV TEST

\begin{tabular}{|c|c|c|}
\hline & $\begin{array}{l}\text { Students } \\
\text { Attitudes }\end{array}$ & $\begin{array}{l}\text { Learning } \\
\text { Results }\end{array}$ \\
\hline 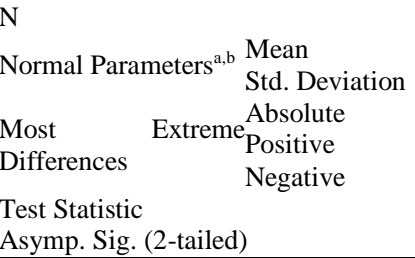 & $\begin{array}{l}60 \\
91.25 \\
10.833 \\
.115 \\
.096 \\
-115 \\
.115 \\
.056^{c}\end{array}$ & $\begin{array}{l}60 \\
63.50 \\
8.991 \\
.068 \\
.068 \\
-.056 \\
.068 \\
.200^{\mathrm{c}, \mathrm{d}} \\
\end{array}$ \\
\hline
\end{tabular}

From Table II above, it can be seen Asymp value. Variable Sig.2-tailed students attitudes toward math lessons are 0:56, and the variable learning outcomes were 0.200. Both grades Asymp. Sig.2-tailed for each of the variable value was greater than alpha level of 0.05 , it can be concluded that the data were normally distributed.

TABLE III NORMALITY TEST DATA By ONE-SAMPLE KOLMOGOROVSMIRNOV TEST

\begin{tabular}{|c|c|c|}
\hline & $\begin{array}{l}\text { Students } \\
\text { Attitudes }\end{array}$ & $\begin{array}{l}\text { Learning } \\
\text { Results }\end{array}$ \\
\hline 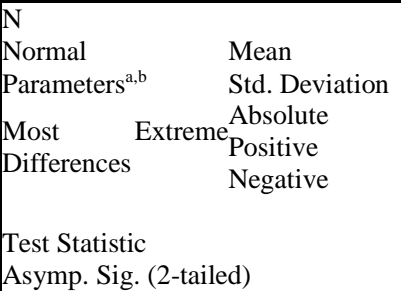 & $\begin{array}{l}60 \\
91.25 \\
10.833 \\
115 \\
.096 \\
-.115 \\
115 \\
.056^{\mathrm{c}}\end{array}$ & $\begin{array}{l}60 \\
63.50 \\
8.991 \\
.068 \\
.068 \\
-.056 \\
.068 \\
.200^{\mathrm{c}, \mathrm{d}}\end{array}$ \\
\hline
\end{tabular}

Based on the above table, the normality test results showed that for the calculation of Kolmogorov-Smirnov test for each variable had a value Asymp. Sig.2-tailed respectively each variable. Variable Attitude 0.056 and 0.200 variable results. Third Asymp value. Sig.2-tailed for each of the variable value was greater than alpha level of 0.05 , it can be concluded that the data were normally distributed.

Linearity test according to Nisfiannor (2009: 92) is performed to determine whether the relationship between the dependent and independent variables is linear (straight line). Linearity test conducted by $\mathrm{F}$ test, if the value of $\mathrm{F}$ count is smaller than the $\mathrm{F}$ table at significance level of $5 \%$ as well as the significance value greater than $5 \%$, then the data will have a linear relationship [12].

Based on Table III above, it can be concluded that the relationship between students attitudes and math lesson where $\mathrm{F}$ count $<\mathrm{F}$ table $(2,626<4,00)$ then the variance of the 
relationship between students' attitudes toward arithmetic and mathematics learning outcomes is linear.

The hypothesis testing of this study used Pearson Product Moment correlation techniques on students' attitudes toward count learning variable. The hypotheses are as follows: $\mathrm{H}_{\mathrm{o}}$ : There is no relationship between students' attitudes and math learning outcomes in mathematics at SDN Cindai Alus 1 Kab. Banjar.

$\mathrm{H}_{\mathrm{a}}$ : There is a relationship between students' attitudes and learning numeracy to math learning outcomes in SDN Cindai Alus $1 \mathrm{Kab}$. Banjar.

TABLE IV RESULTS OF THE CORRELATION BETWEEN STUDENTS' ATTITUDES AND NUMERACY LEARNING IN MATHEMATICS OUTCOMES AT SDN CINDAI ALUS 1 KAB. BANJAR

\begin{tabular}{|c|c|c|c|c|c|c|c|}
\hline & & & $\begin{array}{l}\text { Sum o } \\
\text { Squares }\end{array}$ & & $\begin{array}{l}\text { Mean } \\
\text { Square }\end{array}$ & $\mathbf{F}$ & Sig. \\
\hline \multirow{6}{*}{$\begin{array}{l}\text { Learning } \\
\text { results } \\
\text { students } \\
\text { attitudes }\end{array}$} & \multirow{4}{*}{$\begin{array}{l}\text { Between } \\
\text { *Groups }\end{array}$} & (Combined) & 3742.333 & 31 & 120.720 & \multirow{6}{*}{$\begin{array}{l}3.292 \\
23.271 \\
2.626\end{array}$} & \multirow{6}{*}{$\begin{array}{l}.001 \\
.000 \\
.006\end{array}$} \\
\hline & & Linearity & 853.260 & 1 & 853.260 & & \\
\hline & & Deviation & 2889.074 & 30 & 96.302 & & \\
\hline & & $\begin{array}{l}\text { from } \\
\text { Linearity }\end{array}$ & & & & & \\
\hline & \multicolumn{2}{|c|}{ Within Groups } & 1026.667 & 28 & 36.667 & & \\
\hline & \multicolumn{2}{|l|}{ Total } & 4769.000 & 59 & & & \\
\hline
\end{tabular}

Based on Table IV, it was obtained the Sig. 0.001 $<0.05$, it can be concluded that there was a relationship between the students' attitudes and mathematics learning outcomes or in other words, $\mathrm{H}_{0}$ was rejected and $\mathrm{Ha}$ was accepted.

Meanwhile, to see the level of relations between the two variables, it was obtained by comparing the value of $r$ tables that can be gained through $r$ Product Moment table with the number of $\mathrm{df}=60(\mathrm{df}=\mathrm{n}-1)$ at the $5 \%$ significance level that is equal to 0.254 . The value of $r$ count $>r$ table $(0,423>0.254)$, then the level of the relationship of variable students attitudes to learning outcomes was significant.

This indicates that the higher the students' attitudes toward math, the higher the obtained students learning results are. Conversely, the lower the students' attitudes toward math the lower the obtained results learning are. The result of this study showed that math learning outcomes scores of the fourth grade students of SDN Cindai Alus 1 is quite satisfactory with a percentage of $70 \%$ and the range of scores $(54.509-71.991)$. This is partly due to the different students' ability to understand the material given, learning strategies applied by teachers in the classroom, and students' readiness to accept a given subject matter.

According to the table of the results of correlation between students' attitudes and learning outcomes in mathematics at SDN 1 Banjar Cindai Alus obtained $r$ count at 0.423 and Sig. 0,001 . This result showed that students' attitudes were significantly related to the results of studying mathematics at SDN Cindai Alus 1 Banjar, meaning that the higher the students' attitudes toward math, the higher the students math learning outcomes. Conversely, the lower the students' attitudes toward math, the lower the students math learning outcomes.
Meanwhile, in terms of the degree of closeness between variables, the correlation criterion was 0.423 showing that there is a relationship between students attitudes and mathematics learning outcomes. It is under low category. Low positive attitude category toward math impacting the students learning outcomes they gained. Therefore, in the context of the classroom, every teacher is responsible for developing a positive attitude toward mathematics material on all students that will be useful to solve problems in their future life.

This is in accordance with the opinion of Huang and Lin [3] that the students 'attitudes toward math plays an important role in the learning process, students' positive attitude toward math is correlated with high achievement as well. In addition, in developing a positive attitude, evaluation position in learning is very important and cannot be separated from the learning activities.

\section{CONCLUSIONS AND SUGGESTIONS}

Based on the research that has been done, it can be concluded that there is a relationship between the students attitudes to solve counting problems and the students math learning outcomes at SDN Cindai Alus 1 Banjar. These findings suggest that the higher the students' attitude to solve counting problems, the higher their math learning outcomes.

Some insight on this research is namely: first, students should be positive on math and realize the duties and responsibilities of studying and practice, as well as the willingness to accept arithmetic without coercion to gain knowledge and mastery in math. In mathematics there are prerequisites material that must be controlled by the students before the next material is given. Therefore, it is necessary to study, practice, in order, thorough, and organized more in the effort on answering the questions. Students should not feel satisfied with the score they obtained now to get more optimal learning results.

Second, teachers should foster and enhance a positive attitude and a sense of responsibility in students both in the aspects of academic and non-academic by taking into account the personality and characteristics of each student individually to prepare a plan and present the lessons with good and attractive not only to master the material, but mastering a lesson counting as a knowledge base for the next steps. Giving routine testing should be given by teachers to determine students mastery of the lessons given both advantages and weaknesses as a basis of learning improvement.

Third, the Institute of Education Workforce Education (LPTK) in this case PGSD as an educational institution that produces prospective elementary school teachers should be a model and provide adequate opportunities and provide intensive training to begin designing the learning activities and doing it with the learning practice through simulation activities with their friends in class. A positive attitude of students in mathematics learning can be enhanced by including as much material as other science coverage in discussing mathematics through a thematic approach in which the material is taught integrated with other subjects according to the KTSP curriculum and the 2013 curriculum. 
This research still needs to have further comprehensive research, by examining psychological factors other than those examined in this study to investigate wider with other variables associated with an increase in other learning outcomes with more samples.

\section{REFERENCES}

[1] Susanto, Ahmad, Teori Belajar dan Pembelajaran di Sekolah Dasar. Jakarta: Kencana, 2013.

[2] Balitbang Kemdikbud. "TIMSS (Trends In International Mathematics and Science Study)". http://Litbang.komdikbud.go.id/index.php/timss. Tanggal 6 Maret 20162011.

[3] Lin, Shu-Hui \& Yun Chen Huang. "Development and Application of a Chinese Version of the Short Attitude Toward Mathematics Inventory". International Journal of Science and Mathematics Education. 2016.

[4] Bell,F.H. Teacching and Learning Matematics in Seccndary School. Iowa: Brown Company, 1978

[5] Higgins, John L. Mathematics Teaching and Learning. Worthington: Ohio, 1983.

[6] Grounlund, Measurment And Evaluation Intheaching: New York: mac Milion Publishing Co,1993.

[7] Suprijono Agus. Cooperative Learning Teori dan Aplikasi PAIKUM, 2012.

[8] Gagne. Robert M. The Condotions of Learning. New York: Holt, Rinchart and Winston, 1977.

[9] Reigeluth. Charles M. Intructional Design Theories and Models. London: Lawrence Erlbaum Associates Publishers, 1999.

[10] Crutchfield D. Krech, R.S., and Ballachey, E.L. Individual in Sociaty. Tokyo: Mc Craw-Hill Book Company,1988.

[11] Sanjaya. Wina. Strategi Pembelajaran Berorientasi Standar Proses Pendidikan. Jakarta: Kencana, 2006.

[12] Syarifudin, Anwar. Metode Penelitian.Yogyakarta: Pustaka Pelajar, 2011. 